LINGUA, Vol. 16, No. 1, Maret 2019

p ISSN: 1979 9411; e ISSN: 2442 238X

Http://lingua.pusatbahasa.or.id; Email:presslingua@gmail.com

Center of Language and Cultural Studies, Surakarta, Indonesia

Siregar, Sari Nelda \& Liliani, Else. 2019. Hegemoni pada Cerpen Wajah Itu Membayang

di Piring Bubur Karya Indra Tranggono: Analisis Wacana Kritis.

Lingua (2019), 16(1): 77 92. DOI: 10.30957/lingua.v16i1.576.

\title{
HEGEMONI PADA CERPEN WAJAH ITU MEMBAYANG DI PIRING BUBUR KARYA INDRA TRANGGONO: ANALISIS WACANA KRITIS
}

\author{
Nelda Sari Siregar ${ }^{1} \&$ Else Liliani $^{2}$ \\ Program Pascasarjana Pendidikan Bahasa dan Sastra Indonesia \\ Universitas Negeri Yogyakarta \\ Jl. Colombo No.1, Karang Malang, Caturtunggal, Kec. Depok, \\ Kabupaten Sleman, Daerah Istimewa Yogyakarta 55281 \\ email: ${ }^{1}$ neldasiregar908@yahoo.com; ${ }^{2}$ else 1@uny.ac.id
}

\begin{abstract}
The purpose of the study was to describe the dimensions of the text, the practice of discourse, socio-cultural practices, and the ideological formations in the short stories that face imagined on porridge plates. The theory used is the theory of sociology of Gramci hegemony. The method used is a qualitative method with the Fairclouhg model of critical discourse analysis techniques. The results of the study are: a form of hegemony when traditional markets turn into modern markets and make people have a consumptive lifestyle. The author expresses his criticism of the current phenomenon subtly with the symbol of genderuwo which has greed and hegemonic character. Genderuwo is represented as a capitalist system which is currently controlling society. The form of ideological formation in the form of authoritarianism-capitalism and humanisticmysticism. There are groups of hegemony, pro-hegemony, and groups of counter-hegemony. The hegemony group is the main actor in the occurrence of hegemony (the dominant group), while the pro-hegemony group is a figure who supports the occurrence of hegemony, the counter-hegemony group consists of people who oppose the occurrence of hegemony (cultural rise).
\end{abstract}

Keywords: Hegemony, Capitalism, Fairclough Critical Discourse

DOI: $10.30957 /$ lingua.v16i1.576.

\section{PENDAHULUAN}

Sastra merupakan cabang dari seni yang merujuk pada sebuah hasil cipta manusia yang mengandung estetika dan nilai. Seni yang berupa sastra disampaikan melalui bahasa sehingga bahasa memiliki peran penting dalam sebuah karya sastra. Oleh karena itu, Werren dan Wellek (2014:17) mendefinisikan bahwasanya sastra sebagai karya yang imajinatif dalam wujud bahasa dan mempunyai nilai estitika dominan. Kajian yang secara khusus membahas mengenai hubungan karya sastra dengan gejala sosial di dalam masyarakat yang tidak hanya melihat unsur teks sastra itu sendiri tetapi lebih menekankan pada gejala sosial yang tergambar di dalam karya sastra tersebut merupakan sebuah kajian sosiologi sastra. 
LINGUA, Vol. 16, No. 1, Maret 2019

p ISSN: 1979 9411; e ISSN: 2442 238X

Http://lingua.pusatbahasa.or.id; Email:presslingua@gmail.com

Center of Language and Cultural Studies, Surakarta, Indonesia

Siregar, Sari Nelda \& Liliani, Else. 2019. Hegemoni pada Cerpen Wajah Itu Membayang

di Piring Bubur Karya Indra Tranggono: Analisis Wacana Kritis.

Lingua (2019), 16(1): 77 92. DOI: 10.30957/lingua.v16i1.576.

Sosiologi sastra merupakan suatu disiplin yang tanpa bentuk, tidak terdefinisikan dengan baik, terdiri dari sejumlah studi-studi empiris dan berbagai percobaan pada teori yang lebih general serta mempunyai kesamaan dalam hal semua yang terdapat hubungan antara seni/ kesusastraan dengan masyarakat (Wolff dalam Faruk, 1994:3). Sejalan dengan hal itu, Damono (1979:1) mengatakan bahwa sosiologi sastra sering kali didefinisikan sebagai salah satu pendekatan yang dalam kajian sastra yang memahami dan menilai karya sastra dengan mempertimbangkan segi-segi kemasyarakatan. Tentu dalam realita kehidupan bermasyarakat hubungan antarmanusia kerap terjadi polemik yang berkaitan dengan kekuasaan. Sebab, hakikatnya manusia merupakan mahluk yang menginginkan pengakuan atas eksistensi dirinya dalam kehidupan yang akhirnya melahirkan kesenjangan-kesenjangan antara orang kelas atas (dominan) dan kelas bawah (subordinat).

Polemik-polemik yang terjadi karena adanya hegemoni kapitalis yang secara tidak sadar masyarakat Indonesia telah mengalaminya memunculkan adanya wacana perlawanan pihak-pihak subordinat terhadap pihak dominan yang ingin mengukuhkan kekuasaannya baik secara represif (dominasi) maupun hegemonik. Selanjutnya, Faruk (1994:74) menjelaskan bahwa sebagai salah satu situs hegemoni, dalam karya sastra terdapat formasi ideologi. Berdasarkan hal tersebut, hegemoni berkaitan dengan model kekuasaan yang berupaya untuk menjaga stabilitas kekuasaan terhadap kelas-kelas sosial yang dikuasainya.

Di Indonesia yang saat ini menganut demokrasi pancasila, tidak urung sistem kapitalis terus berkembang. Kapitalis erat hubungannya dengan proses ekonomi dan pengindustrian yang termasuk ke dalam hegemoni. Artinya, melalui sistem kapitalis akan adanya bentuk penguasaan dan kemampuan mengatur kelompok-kelompok lawannya. Dalam teori hegemoni yang diungkapkan Gramci, hegemoni diciptakan dari kekuatan material yang di sini adalah ideologi dan di dalam karya sastra akan terdapat formasi ideologi yang mengungkap bentuk-bentuk sistem kapitalis yang secara praktiknya sedang terjadi saat ini maka melalui karya sastra dapat mengungkap praktikpraktik kapitalis yang secara tidak sadar bahwa masyarakat Indonesia sudah dilingkari oleh sistem tersebut.

Berdasarkan hal tersebut, lahirlah karya sastra dengan berbagai bentuk seperti cerita pendek (cerpen) yang menjadi sebuah sarana digunakan oleh pengarang untuk menyampaikan kegelisahan yang dirasakannya. Pada cerpen karangan Indra Tranggono terdapat beberapa karyanya yang mengkritisi sistem kapitalis di Indonesia yang sebagian besar menceritakan kehancuran kemanusiaan oleh kapitalisme. Untuk menguak lebih dalam lagi hal-hal yang ingin disampaikan oleh penulis terkait fenomena sosial pada sistem ekonomi di Indonesia saat ini maka melalui cerpen harus diungkap secara kritis menggunakan teknik analisis wacana kritis Fairclough. dengan teori hegemoni yang diperkenalkan oleh Gramsci untuk menganalisis karya sastra Indra Tranggono yang terdapat pada kumpulan cerpen kompas yang berjudul Wajah Itu Membayang di Piring Bubur. Berdasarkan uraian latar belakang di atas, dapat dirumuskan permasalahan dalam makalah ini yaitu: (1) bagaimana dimensi teks dalam cerpen Wajah Itu Membayang di Piring Bubur? (2) bagaimana praktik wacana dalam 
LINGUA, Vol. 16, No. 1, Maret 2019

p ISSN: 1979 9411; e ISSN: 2442 238X

Http://lingua.pusatbahasa.or.id; Email:presslingua@gmail.com

Center of Language and Cultural Studies, Surakarta, Indonesia

Siregar, Sari Nelda \& Liliani, Else. 2019. Hegemoni pada Cerpen Wajah Itu Membayang

di Piring Bubur Karya Indra Tranggono: Analisis Wacana Kritis.

Lingua (2019), 16(1): 77 92. DOI: 10.30957/lingua.v16i1.576.

cerpen Wajah Itu Membayang di Piring Bubur? (3) bagaimana praktik sosio-budaya dan formasi ideologi yang ada dalam cerpen Wajah Itu Membayang di Piring Bubur?. Tujuan penelitian ini adalah untuk mendeskripsikan dimensi teks, praktik wacana, praktik sosio-budaya, dan formasi ideologi yang ada dalam cerpen Wajah Itu Membayang di Piring Bubur.

Keberadaan karya sastra sering kali dianggap sebagai sesuatu yang memiliki kekuatan untuk membentuk, mempengaruhi, bahkan juga mengubah masyarakat karena ada keyakinan tersebut, maka tidaklah aneh kalau kita sering mendengar seorang pengarang mengalami pencekalan ataupun ancaman dari pihak tertentu setelah menerbitkan karya sastranya.

Teori hegemoni dikemukakan oleh Antonio Gramsci. Teori tersebut sering kali disebut juga sebagai teori kultural/ideologis general dan digunakan untuk memahami bentuk-bentuk politis, kultural, dan ideologi yang dianggap memiliki kekuatan untuk memformasi masyarakat karena dirumuskan oleh Gramsci, maka dalam wacana sosiologi, teori ini lebih dikenal dengan nama teori hegemoni Gramsci (Faruk, 1994:61). Persoalan kultural dan formasi ideologis menjadi penting bagi Gramsci karena di dalamnya pun berlangsung proses yang rumit.

Hegemoni diciptakan oleh suprastruktur/kekuatan, material/ideologi. Hegemoni di sini adalah untuk memperkuat infrastruktur. Suprastruktur berkaitan dengan masalah kultural, sedangkan infrastruktur berkaitan dengan struktur material. Subjek-subjek yang mengisi struktur senantiasa diciptakan dan direproduksi sehingga subjek-subjek yang terhegemoni semakin terjaga dan terpelihara. Sebagai salah satu situs hegemoni, di dalam karya sastra terdapat formasi ideologi. Formasi adalah suatu susunan dengan hubungan yang bersifat bertentangan, korelatif, dan subordinatif. Formasi ideologi tidak hanya membahas ideologi yang terdapat di dalam teks tetapi juga membahas bagaimana hubungan antara ideologi-ideologi.

\section{METODE}

Analisis cerpen Wajah Itu Membayang di Piring Bubur karya Indra Tranggono ini menggunakan metode kualitatif dengan teknik analisis wacana kritis model Fairclough. Fairclough (1995:216 ) mengungkapakan seputar tiga dimensi kerangka analisis yang digambarkan dalam sebuah wacana yaitu: teks, praktik wacana, dan praktik sosiokultural (Eriyanto, 2015:289) menguraikan dengan jelas tahapan analisis wacana kritis yang dikembangkannya dari Fairclough. Pertama, dimensi teks (text) dianalisis secara linguistik, khususnya mengamati lexical choices yang terdapat di dalam cerpen. Kedua, praktik wacana (discourse practice) adalah dimensi yang berhubungan dengan teks itu diproduksi. Dimensi ini juga disebut dengan tataran meso di mana untuk melihat rujukan-rujukan yang digunakan di dalam sebuah cerpen dan akan dilihat interdiskursivitas serta intertekstualitasnya. Ketiga, analisis praktik sosial (sociocultural practice) adalah dimensi yang didasari pada asumsi bahwa konteks sosial yang ada di luar teks yang mempengaruhi bagaimana wacana itu muncul. Untuk itu, melalui ketiga dimensi yang dikemukakan oleh Fairclough dapat menghubungkan tataran mikro hingga praktik sosial untuk mengetahui muatan ideologis dibalik cerpen tersebut. 
LINGUA, Vol. 16, No. 1, Maret 2019

p ISSN: 1979 9411; e ISSN: 2442 238X

Http://lingua.pusatbahasa.or.id; Email:presslingua@gmail.com

Center of Language and Cultural Studies, Surakarta, Indonesia

Siregar, Sari Nelda \& Liliani, Else. 2019. Hegemoni pada Cerpen Wajah Itu Membayang di Piring Bubur Karya Indra Tranggono: Analisis Wacana Kritis.

Lingua (2019), 16(1): 77 92. DOI: 10.30957/lingua.v16i1.576.

\section{HASIL DAN PEMBAHASAN}

\subsection{Dimensi Teks dalam Cerpen Wajah Itu Membayang di Piring Bubur}

Pada cerpen ini pengarang menghadirkan beberapa tokoh untuk mengkontruksikan hegemoni yang ada di dalam cerita tersebut secara kompleks. Penggunaan teknik naming dilakukan oleh pengarang sebagai bentuk untuk mendukung maksud dari cerita yang diangkat. Sebab, banyak sekali pemilihan nama pada setiap tokoh yang mendukung maksud cerita karena sesuai dengan karakteristik setiap tokoh yang dihadirkan. Tokoh-tokoh yang mendominan adalah Murwad, Sumbi, Ki Dono Driyah, Gendoruwo, Bragalba, dan Pemeriksa (Polisi).

Tokoh utama yang dihadirkan pengarang adalah Murwad. Sosok lelaki yang bekerja sebagai tukang sapu dan penjaga malam di pasar dituduh sebagai dalang terjadinya kebakaran di Pasar Kliwon. Murwad harus mendekap di sel tahanan atas tuduhan dengan sengaja membakar pasar padahal ia tidak melakukan perbuatan tersebut. Namun, ketika di dalam sel tahanan ia sudah lebih seminggu tidak mau makan tetapi semangatnya tetap tinggi untuk tidak menyerah. Hal tersebut terbukti dengan karakteristik tokoh yang dihadirkan pengarang dengan memilih diksi untuk tokoh tersebut adalah Murwad. Murwad berasal dari Arab (Islam) yang memiliki makna keinginan, cita, dan kemauan. Melalui tokoh Murwad ini pengarang ingin menghadirkan seorang yang memiliki kemauan dan keinginan yang kuat untuk melawan kekuasaan-kekusaan yang dilakukan oleh kelas dominan terhadap kelas bawah seperti dirinya karena berdasarkan status sosial tokoh Murwad hanya sebagai tukang sapu dan penjaga malam di sebuah pasar yang notabenenya tidak memiliki daya untuk menguasai orang lain. Hal tersebut terbukti dalam kutipan di bawah ini yaitu sebagai berikut.

Di sel tahanan, sudah lebih seminggu Murwad tidak mau makan. Makanan itu dibiarkan saja dirubung lalat. Ia merasakan tubuhnya lemas dan panas. Namun, semangatnya tetap tinggi untuk tidak menyerah. Para sipir selalu membujuknya untuk mau makan. Namun selalu ditolaknya.

Tokoh Murwad juga digambarkan memiliki hasrat keduniaaan yaitu dengan istilah kamunungsan. Untuk itu, melalui Eyang Dono pengarang ingin menyampaikan pesan bahwasanya manusia harus mengendalikan nafsu dunianya dengan cara berpuasa. Sebab secara hakikatnya puasa adalah mengendalikan hawa nafsu lahir dan batin. Dalam kepercayaan jawa ada yang dikenal dengan budaya kebatinana orang Jawa di mana untuk memperoleh kemampuan batin maka harus melepaskan diri dari dunia kebendaan, yaitu memiliki sifat reka untuk melepaskan segala hak milik, pikiran atau perasaan untuk memiliki, serta keinginan untuk memiliki. Sikap menyerah serta mutlak ini tidak boleh dianggap sebagai tanda sifat lemahnya seseorang, sebaliknya ia menandakan bahwa orang seperti itu memiliki kekuatan batin dan keteguhan iman. Kemampuan untuk membebasakan diri dari dunia kebendaan dan kehidupan duniawi juga melibatkan sikap narima yaitu sikap menerima nasib dan sikap bersabar. Kemampuan untuk memiliki sikap semacam itu dapat diperoleh dengan hidup 
LINGUA, Vol. 16, No. 1, Maret 2019

p ISSN: 1979 9411; e ISSN: 2442 238X

Http://lingua.pusatbahasa.or.id; Email:presslingua@gmail.com

Center of Language and Cultural Studies, Surakarta, Indonesia

Siregar, Sari Nelda \& Liliani, Else. 2019. Hegemoni pada Cerpen Wajah Itu Membayang

di Piring Bubur Karya Indra Tranggono: Analisis Wacana Kritis.

Lingua (2019), 16(1): 77 92. DOI: 10.30957/lingua.v16i1.576.

sederhana dalam arti sesungguhnya. Berdasarkan pernyataan di atas dapat dilihat pada kutipan sebagai berikut.

"Saya ingin melihatnya. Bisakah Eyang membantu?"

"Kamu belum siap. Kamu masih kamanungsan. Kamu mesti membebaskan diri dari hasrat-hasrat kemanusiaanmu. Berpuasalah. Kuat?"

Pada kutipan di atas pengarang ingin memasukkan unsur nasihat di dalamnya bahwasanya manusia harus menghilangkan hasratnya yang ingin selalu memiliki sesuatu. Hal tersebut sejalan dengan perilaku kaum kapitalis yang memiliki tujuan untuk menguasai apapun demi merauk keuntungan dalam hal ini perekonomian. Untuk itu, sebagaimana mestinya manusia yang hidup di dunia hanya sementara tidak semestinya untuk berprilaku tamak dalam kehidupan dunia. Sikap dengan hidup sederhana mencerminkan rasa syukur dan keteguhan iman seseorang tanpa harus menuruti nafsu dunia.

Tokoh kedua yang dihadirkan pengarang adalah Sumbi, istri Murwad. Sumbi yang memiliki sifat kesetian yang amat besar dengan suaminya dan selalu menyiapkan sepiring bubur gula jawa kesukaan Murwad seraya mengucap doa untuk keselamatan Murwad yang belum pulang hingga pasca kebakaran dan terbayang wajah Murwad. Pemilihan diksi bubur gula jawa tentu memiliki maksud oleh pengarang bahkan dijadikan sebuah judul di dalam cerpen ini yaitu Wajah Itu Membayang di Piring Bubur. Wajah yang membayang adalah sosok Murwad suaminya yang hilang pasca kebakaran dan Sumbi selalu menghaturkan doa pada sepiring bubur. Berdasarkan tradisi di Jawa bubur tidak hanya sebuah kuliner biasa. Dalam masyarakat Jawa bubur memiliki filosofi yang dalam, bubur yang juga disebut jenang merupakan makanan yang memiliki banyak doa dan pengharapan mulia. Kebudayaan masyarakat Jawa yang tersebar dari Jawa Tengah hingga Jawa Timur, bubur atau jenang untuk keperluan ritual budaya terdapat tujuh macam karena bahasa Jawa tujuh itu pitu, sehingga orang Jawa sering memberikan singkatan dari pitulangan yaitu minta permohonan kepada Tuhan agar hajatnya dikabulkan. Hal tersebut dapat dilihat pada kutipan di bawah ini yaitu sebagai berikut.

Selalu setiap hari, Sumbi menyiapkan bubur gula jawa kesukaan Murwad, suaminya. Bubur itu ia buat sendiri, dari beras terbaik rojo lele yang dicampur santan kelapa kental, sedikit garam dan ditaburi gerusan gula jawa. Setiap menyajikan bubur itu, mulut Sumbi selalu mengucap doa untuk keselamatan Murwad yang hingga kini belum pulang.

Berdasarkan keyakinaan masyarakat terhadap filosofi bubur atau jenang masih kental terbukti dengan yang dilakukan oleh Sumbi yang memohon agar suaminya segera pulang. Penyajian bubur tersebut terbilang sederhana yakni sebagai tolak balak atau membuang kesialan. Masyarakat Jawa yang dulu menganut kepercayaan kapitayan sudah punya kepercayaan dengan adanya kekuasaan di atas segala sesuatu. Bubur 
LINGUA, Vol. 16, No. 1, Maret 2019

p ISSN: 1979 9411; e ISSN: 2442 238X

Http://lingua.pusatbahasa.or.id; Email:presslingua@gmail.com

Center of Language and Cultural Studies, Surakarta, Indonesia

Siregar, Sari Nelda \& Liliani, Else. 2019. Hegemoni pada Cerpen Wajah Itu Membayang

di Piring Bubur Karya Indra Tranggono: Analisis Wacana Kritis.

Lingua (2019), 16(1): 77 92. DOI: 10.30957/lingua.v16i1.576.

direpresentasikan sebagai sikap yang kembali ke fitrah dan kembali kepada Tuhan yang Maha Esa. Manusia berserah diri kepada Tuhan agar diberi keberkahan dan keselamatan. Manusia hanya bisa berusaha bagaimana baiknya, tetapi tetap ada kekuatan dan kekuasan yang lebih besar. Oleh karena itu, makna penyerahan diri adalah pasrah dengan hasil usaha yang sudah atau akan dilakukan.

Dalam perkembangnnya setelah masuknya agama. Selamatan bubur ini kemudian disesuaikan. Utamanya bacaan doa yang dilantunkan. Namun, tetap tidak mengubah keberadaan panganan ini. Untuk agama Islam, makna penyerahan diri juga tertuang dalam doa Laa haula wa laa quawata illa billah yang artinya tiada pertolongan dan kekuatan melainkan hanya dengan pertolongan dan kekuatan Allah semata. Artinya, pengarang mencoba mengangkat filosofi bubur yang diyakinin oleh masyarakat sebagai bentuk representasi doa-doa yang dihaturkan oleh tokoh Sumbi terhadap Murwad, suaminya. Hal tersebut juga mendukung bahwasanya latar cerita yang diangkat dalam ini berada di Jawa Tengah. Hegemoni yang diangkat oleh pengarang adalah hegemoni yang realitanya terjadi di daerah Jawa Tengah sebagai daerah yang menjadi fokus pelaku kapitalis.

Tokoh ketiga yang dihadirkan oleh Pengarang adalah Ki Dono Driyah atau Eyang Dono. Tokoh ini menyimbolkan sosok yang memberontak akan keadaan saat ini yaitu sistem kapitalis yang mulai masuk di Indonesia. Kapitalisme memang sudah masuk pada sistem di Indonesia, masyarakat sudah begitu mendewakan produk-produk kapitalisme. Kaum kapitalis akan menggunakan berbagai cara untuk mencapai tujuannya yaitu dengan jurus memakan perusahaan kecil. Contohnya, jika di suatu wilayah banyak terdapat toko kelontong yang kecil atau sebuah pasar tradisional maka cukup dibangun sebuah mal yang besar. Dengan begitu toko-toko itu akan tutup dengan sendirinya dan mengalami gulung tikar. Eyang Dono juga dihadirkan sebagai sosok penolong tokoh Murwad ketika kebakaran terjadi. Kehadiran Eyang Dono yang menolong Murwad sebagai bentuk representasi untuk menyadarkan manusia dari sistem kapitalis yang kejam sekaligus untuk memberontak dan menuntut keadilan ketika Murwad dituduh sebagai dalang kebakaran pasar yang merupakan ulah kaum kapitalis. Hal tersebut terdapat dalam kutipan sebagai berikut.

\section{Tubuh Murwad melayang memasuki lapisan-lapisan ruang. Ketika tubuh itu hendak jatuh, mendadak ada tangan yang terulur dan menangkapnya. Murwad kaget. Namun, sang penolong itu membujuknya untuk tenang lewat senyuman.}

Selain itu, terdapat juga lexchical choice yaitu betapa 40 hari untuk mendapat wahyu pasar merupakan sebuah tradisi orang Jawa di mana ketika memiliki suatu hajat yang besar maka akan bertapa selama 40 hari penuh. Orang-orang yang masih memegang teguh budaya jawa maka akan kental sekali dengan tradisis spiritual kejawen.

Pengarang juga memilih diksi jagat kelanggengan yang dituturkan oleh $\mathrm{Ki}$ Dono. Jagat kelanggengan merupakan alam setelah kematian yang dipercayai oleh 
LINGUA, Vol. 16, No. 1, Maret 2019

p ISSN: 1979 9411; e ISSN: 2442 238X

Http://lingua.pusatbahasa.or.id; Email:presslingua@gmail.com

Center of Language and Cultural Studies, Surakarta, Indonesia

Siregar, Sari Nelda \& Liliani, Else. 2019. Hegemoni pada Cerpen Wajah Itu Membayang

di Piring Bubur Karya Indra Tranggono: Analisis Wacana Kritis.

Lingua (2019), 16(1): 77 92. DOI: 10.30957/lingua.v16i1.576.

manusia. Dalam agama Islam disebut dengan alam barzah yaitu alam kedua setelah kematian. Di mana amal baik dan buruk yang akan menolong atau bahkan menyiksa manusia nantinya. Sifat-sifat serakah dan hegemonik merupakan sifat yang tidak baik dalam ajaran agama apapun termasuk agama Islam untuk itu sejatinya keduniaan hanya bersifat sementara. Untuk itu, tidak perlu terlalu mengejar duniawi. Hal tersebut terdapat dalam kutipan sebagai berikut.

\section{"Ruang awung-uwung. Tempat istirah jiwa-jiwa sebelum meneruskan perjalanan menuju Jagat Kelanggengan."}

Tokoh keempat yang dihadirkan adalah sosok hantu Genderuwo. Namun, yang dimaksud di sini bukanlah sosok hantu genderuwo yang sebenarnya diyakini oleh masyarakat sebagai mahluk gaib. Genderuwu sebagai representasi dan lambang kapitalisme yang selalu melahirkan problema kemanusiaan, karena wataknya yang rakus dan hegemonik. Dalam mitologi jawa genderuwo adalah hantu yang berwujud raksasa dan selalu menggangu serta memperdaya manusia karena ia ingin menguasai kehidupan manusia. Begitu pula yang ingin disampaikan oleh pengarang bahwasanya sistem kapitalis akan berujung pada ketidakadilan terhadap kelas subordinat dan melakukan penghisapan sehingga menghancurkan nilai-nilai kemanusiaan. Hal tersebut sangat relevan dengan keadaan saat ini di mana banyak sekali kisah-kisah pedagang tradisional harus gulung tikar karena tidak mampu bersaing dengan pelaku kapitalis. Hal tersebut dapat dilihat pada kutipan sebagai berikut.

"Aku tidak tahu persis. Tapi, sejak pasar itu dihuni Genderuwo, suasana jadi aneh. Gerah. Genderuwo itu selalu meniupkan hawa panas dalam setiap aliran darah, hingga orang-orang saling membunuh."

"Tapi di pasar itu, saya tidak pernah melihat perkelahian atau mayatmayat...."

"Karena kamu tidak melihatnya dengan mata batin."

"Bagaimana wujud Genderuwo itu?"

"Tinggi dan besarnya tak bisa dibayangkan. Tubuhnya berbulu hitam. Kasar. Kuku kaki dan tangannya sangat panjang. Matanya hijau. Bola matanya sangat besar, sepuluh kali lipat dari danau. Tubuhnya bisa berubah menjadi apa saja. Angin. Api. Udara. Dia hadir di mana saja, di setiap belahan dunia. Di setiap hati manusia."

Kutipan di atas wujud genderuwo direpresentasikan sebagai kapitalisme yang secara fisik dituturkan oleh tokoh Eyang Dono bahwa genderuwo memiliki badan tinggi dan besar yang tak bisa dibayangkan. Artinya, yang dimaksud oleh pengarang bahwasanya pelaku kapitalis memiliki kemampuan menguasai ekonomi yang sangat besar khususnya di daerah Jawa yang relevan dengan keadaan saat ini. Selain itu, fisik genderuwo yang memiliki kuku kaki dan tangannya yang panjang dapat direpresentasikan bahwasanya sistem kapitalis memiliki jangkauan yang luas untuk menguasai sesuatu dan dapat dilakukan dengan berbagai cara. Wujud genderuwo yang 
LINGUA, Vol. 16, No. 1, Maret 2019

p ISSN: 1979 9411; e ISSN: 2442 238X

Http://lingua.pusatbahasa.or.id; Email:presslingua@gmail.com

Center of Language and Cultural Studies, Surakarta, Indonesia

Siregar, Sari Nelda \& Liliani, Else. 2019. Hegemoni pada Cerpen Wajah Itu Membayang

di Piring Bubur Karya Indra Tranggono: Analisis Wacana Kritis.

Lingua (2019), 16(1): 77 92. DOI: 10.30957/lingua.v16i1.576.

memiliki mata hijau dan bola mata yang besar direpresentasikan sifat kaum kapitalis. Selama ini warna hijau dikaitkan dengan uang yang sering didengar dengan istilah "Matanya hijau melihat uang". Warna hijau dikaitkan dengan ambisi, keserakahan, dan rasa iri artinya apabila dikaitkan dengan perilaku kapitalis maka sangat relevan bahwasanya pelaku kapitalis memiliki sifat yang rakus, hegemonik, ambisi, dan serakah. Sedangkan wujud genderuwo yang Tubuhnya bisa berubah menjadi apa saja. Angin. Api. Udara. Dia hadir di mana saja, di setiap belahan dunia. Di setiap hati manusia dimaksudkan pengarang sebagai representasi bahwasanya perilaku kapitalis bisa dimiliki setiap orang dengan kelas dominan.

Genderuwo yang menyimbolkan kapitalis merupakan perwujudan realita sekarang yang tersebar di kota-kota besar karena banyak sekali pasar-pasar tradisional yang sudah berubah menjadi bangunan-bangunan megah yang merupakan bentuk sistem kapitalis. Hal tersebut dapat diliat dalam kutipan berikut.

"Eyang.....aku melihat Pasar Kliwon berubah jadi bangunan megah dan indah. Penuh cahaya. Tapi Eyang, aku melihat sosok hitam besar sekali. Ya, dia duduk di sana," mata Murwad terpejam.

"Ya, itulah Genderuwo penguasa pasar!"

"Aduh eyang, mataku tidak kuat. Pandanganku jadi gelap."

"Dia memang sakti sekaligus ganas! Hati-hati. Sekarang lihatlah lagi.

Genderuwo itu masih di sana?"

"Masih...,; Dia menggerakkan tangannya. Tidak hanya dua, tapi banyak sekali. Tangan-tangan itu berubah jadi belalai panjang dan besar. Ya, ampun pasar itu dibelitnya. Gumpalan-gumpalan uang itu dihisapnya."

"Dia lebih dari rakus...."

"Genderuwo itu menoleh, Eyang. Dia menatapku. Matanya hijau bikin silau.

Gigi-giginya gemeretak. Taring-taringnya berkilat-kilat.

Tokoh selanjutnya adalah Wali Kota Bragalba. Bragalba adalah sosok wali kota sebagai pelaku kapitalis yang dengan sengaja membakar pasar tradisional kemudian merubahnya menjadi plaza dan mengkambinghitamkan Murwad sebagai pelaku pembakaran karena kekuasaan yang dimiliknya sebagai wali kota. Pengarang melakukan teknik naming pada tokoh Bragalba sesuai dengan karakteristik tokoh yang dihadirkan. Bragalba adalah salah satu nama wayang yang tergolong sebagai raksasa prepat. Bragalba memiliki badan yang besar, mulutnya terbuka lebar dengan gigi tajam, dan mata melotot yang direpresentasikan dengan sosok konglomerat yang bernama Bragalba memiliki gambaran nafsu berkuasa, serakah, dan rakus relevan dengan perilaku kapitalis sebenarmya. Berdasarkan hal tersebut dapat dilihat dalam kutipan sebagai berikut.

"Dengan berubahnya Pasar Kliwon menjadi Kliwon Plaza maka masa depan itu kini ada dalam genggaman kita. Dinamika ekonomi kota ini akan terus meningkat dengan semakin banyaknya orang belanja." 
LINGUA, Vol. 16, No. 1, Maret 2019

p ISSN: 1979 9411; e ISSN: 2442 238X

Http://lingua.pusatbahasa.or.id; Email: presslingua@gmail.com

Center of Language and Cultural Studies, Surakarta, Indonesia

Siregar, Sari Nelda \& Liliani, Else. 2019. Hegemoni pada Cerpen Wajah Itu Membayang di Piring Bubur Karya Indra Tranggono: Analisis Wacana Kritis. Lingua (2019), 16(1): 77 92. DOI: 10.30957/lingua.v16i1.576.

Wajah Wali Kota Bragalba menyala. Orang-orang tepuk tangan. Ratusan blitz menghujani wajahnya.

"Masyarakat yang suka berbelanja adalah masyarakat yang makmur!"

Bragalba mengunci pidatonya.

Tepuk tangan kembali membahana. Bragalba menekan tombol sirene.

Kliwon Plaza resmi dibuka. Ia pun turun panggung. Para wartawan

langsung menyerbunya.

Tokoh Pemeriksa (Polisi) dihadirkan oleh pengarang sebagai kaum intelektual melalui tugasnya sebagai aparatur negara bisa dimanfaatkan serta difungsikan oleh kelas-kelas dominan untuk mengeksploitasi kelas subordinat untuk mencapai tujuan yang menguntungkan pelaku kapitalis. Hal tersebut dapap dilihat dalam kutipan sebagai berikut.

"Saudara tahu, kenapa saudara ditahan di sini?" ujar seorang pemeriksa dengan ramah.

"Tahu alasannya saudara ditahan?!"

"Tidak. Saya hanya melihat pasar itu tiba-tiba terbakar."

"Bagus. Berarti saudara ada di lokasi ketika itu."

"Iya. Tapi, saya hanya tukang sapu."

"Itu tidak penting. Yang penting, saudara mengakui ada di lokasi."

"Apa tujuan saudara membakar pasar itu?" tanya pemeriksa yang lain.

"Maaf Pak. Kenapa pertanyaan Bapak aneh? Saya tidak membakar."

"Akui saja. Hukuman saudara akan ringan."

"Tapi saya tidak membakar. Tidak, Pak. Tidak."

"Saudara sakit. Saudara perlu dokter."

Beberapa sosok meninggalkan ruangan. Dua petugas menggelandang Murwad menuju sel tahanan.

Pada cerpen ini menggunakan diksi beras rojo lele. Pemilihan beras rojo lele dimaksudkan ketika membuat bubur/jenang adalah beras yang terbaik karena digunakan untuk mengucap doa keselamatan. Rojo lele adalah nama beras dari padi lokal unggulan Indonesia yang berasal dari Jawa Tengah. Berdasarkan hal tersebut latar cerita merujuk pada daerah di Jawa Tengah. Hal tersebut terdapat dalam kutipan sebagai berikut.

Selalu setiap hari, Sumbi menyiapkan bubur gula jawa kesukaan Murwad, suaminya. Bubur itu ia buat sendiri, dari beras terbaik rojo lele.

Penggambaran yang menunjukkan secara spesifik latar pada adalah di Surakarta, Jawa Tengah. Hal tersebut terbukti dengan pemilihan Pasar Kliwon yang menjadi objek penceritaan. Pasar Kliwon adalah salah satu pasar di Surakarta yang berdiri tahun 1980. Namun, sekarang aktivitas pasar tidak begitu hidup karena pasarnya yang sepi. Apalagi sudah terdapat plaza seperti matahari mall, Smart 3 Swalayan, Luwes, Indomaret, dan Alfamart yang berdiri di dekat Pasar Kliwon sehingga menyebabka matinya kegiatan 
LINGUA, Vol. 16, No. 1, Maret 2019

p ISSN: 1979 9411; e ISSN: 2442 238X

Http://lingua.pusatbahasa.or.id; Email:presslingua@gmail.com

Center of Language and Cultural Studies, Surakarta, Indonesia

Siregar, Sari Nelda \& Liliani, Else. 2019. Hegemoni pada Cerpen Wajah Itu Membayang

di Piring Bubur Karya Indra Tranggono: Analisis Wacana Kritis.

Lingua (2019), 16(1): 77 92. DOI: 10.30957/lingua.v16i1.576.

jual beli di pasar tradisional. Tahun 1998 dulu memang benar pernah terjadi kebakaran di Pasar Klewer yang disinyalir dilakukan dengan sengaja oleh orang-orang yang berkepentingan. Kehadiran Plaza dan supermarket merupakan bentuk sistem kapitalis yang dilakukan oleh pelaku-pelaku kapitalis yang dengan sengaja mematikan pasar tradisional dan membangun supermarket-supermarket yang dinilai lebih bagus. Hal tersebut dapat dilihat pada kutipan sebagai berikut.

Mendadak terdengar suara ledakan. Sangat keras. Muncul percikanpercikan api. Makin lama makin membesar. Menjilat-jilat. Api itu terus menjalar membakar apa saja. Murwad berlari pontang-panting. Ia berusaha meloloskan diri dari kepungan api. Tubuhnya menjelma bayangbayang.

"Dengan berubahnya Pasar Kliwon menjadi Kliwon Plaza maka masa depan itu kini ada dalam genggaman kita. Dinamika ekonomi kota ini akan terus meningkat dengan semakin banyaknya orang belanja.

Selain itu, yang menguatkan latar cerita dalam cerpen berada di Pasar Kliwon Surakarta/ Solo berdasarkan sejarahnya yang dimuat dimerdeka.com bahwasanya Pasar Kliwon dahulu memang pernah mempunyai kompleks lokalisasi cukup besar di Kampung Silir, Semanggi, Pasar Kliwon. Tempat pelacuran tersebut kabarnya sudah ada sejak zaman penjajahan Jepang. Silir merupakan nama yan tidak asing lagi bagi masyarakat kota Solo yang merupakan lokalisasi terbesar di kota tersebut. Hal tersebut tergambar dalam kutipan cerpen di bawah ini yaitu sebagai berikut.

Murwad mengayun-ayunkan sapunya. Menghalau belasan pasangan yang sedang asyik masyuk bercinta di sela-sela los pasar. Bangku-bangku dipukulinya. Kursi dan dingklik dilemparkannya. Suara gaduh menjelang subuh itu membuat beberapa pasangan kaget. Mereka bergegas bangun. Langsung berlarian. Ada yang setengah telanjang.

Beberapa pasangan masih bertahan. Ada yang masih berangkulan. Bahkan nekat bercumbu.

"Enak saja bercinta di pasar! Kalau tidak kuat nyewa losmen, ya cari kuburan!" Murwad meradang.

\subsection{Praktik Wacana dalam Cerpen Wajah Itu Membayang di Piring Bubur Karya Indra Tranggono}

Dalam dimensi praktik wacana terdapat dua unsur yang dibidik yaitu: interdiskursivitas dan intertekstual. Interdiskurtivitas adalah rujukan kata-kata yang diungkapkan oleh orang lain yang dirujuk oleh tokoh atau pengarang. Dalam cerpen ini terdapat beberapa interdiskurtivitas yakni, melalui narator dari sudut pandang pengarang orang ketiga sebagai pengamat. Pada tokoh Sumbi menggunakan rujukan kepercayaan atau tradisi orang Jawa berkaitan dengan menyediakan bubur sebagai ritual menolak balak dengan mengucap doa untuk keselamatan untuk suaminya, Murwad. Murwad hilang setelah kejadian kebakaran di Pasar Kliwon. Namun, Sumbi meyakini 
LINGUA, Vol. 16, No. 1, Maret 2019

p ISSN: 1979 9411; e ISSN: 2442 238X

Http://lingua.pusatbahasa.or.id; Email:presslingua@gmail.com

Center of Language and Cultural Studies, Surakarta, Indonesia

Siregar, Sari Nelda \& Liliani, Else. 2019. Hegemoni pada Cerpen Wajah Itu Membayang

di Piring Bubur Karya Indra Tranggono: Analisis Wacana Kritis.

Lingua (2019), 16(1): 77 92. DOI: 10.30957/lingua.v16i1.576.

bahwasanya Murwad masih hidup dan selalu menghaturkan doa-doa kepada Tuhan atas keselamatan suaminya pada sepiring bubur gula jawa sambil membayangkan wajah suaminya. Bubur atau jenang pada masyarakat Jawa juga biasanya digunakan untuk selamatan bayi, musim panen, dan pernikahan. Hal tersebut terdapat dalam kutipan sebagai berikut.

Selalu setiap hari, Sumbi menyiapkan bubur gula jawa kesukaan Murwad, suaminya. Bubur itu ia buat sendiri, dari beras terbaik rojo lele yang dicampur santan kelapa kental, sedikit garam dan ditaburi gerusan gula jawa. Setiap menyajikan bubur itu, mulut Sumbi selalu mengucap doa untuk keselamatan Murwad yang hingga kini belum pulang.

Namun, Sumbi yakin, suaminya itu masih hidup. Dia pasti pulang. Entah kapan. Sumbi berusaha mengulur-ulur harapan itu dengan selalu menyajikan bubur gula jawa buat Murwad. Di hamparan bubur hangat itu, terbayang wajah Murwad. Tersenyum. Dada Sumbi terasa mengembang.

Interdiskurtivitas lainnya yang dirujuk oleh tokoh Murwad adalah kepercayaan orang Jawa bahwasanya tempat yang ada kegiatan maksiat seperti tempat lokalisasi tidak baik dijadikan untuk mencari rezeki. Hal tersebut juga sejalan dengan rujukan ajaran Islam yang mengharamkan pekerjaan sebagai pelacur dan membuka lokalisasi. Sesuai dengan firman Allah SWT berfirman, "Dan janganlah kamu paksa budak-budak perempuanmu untuk melakukan pelacuran, sedang mereka sendiri menginginkan kesucian, karena kamu hendak mencari keuntungan duniawi."Hal tersebut terdapat dalam kutipan sebagai berikut.

"Dasar sundal! Kalian telah mengotori pasar. Gara-gara ulah kalian, pasar jadi sepi. Bakul-bakul bangkrut. Awas, jika kalian masih berani bercinta di sini!" Murwad berteriak-teriak. Suaranya diserap dinding-dinding pasar.

Interdiskurtivitas lainnya, yang dirujuk oleh tokoh Ki Dono Driyah yaitu akan adanya kekuasaan Tuhan dan apabila kita menginginkan sesuatu maka dapat menghaturkan doa-doa kepada Tuhan, Sang pemilik semuanya. Hal tersebut terdapat dalam kutipan sebagai berikut.

"Tuhan mengabulkan permohonanku. Wahyu itu hadir, berpendar-pendar di atas pasar itu. Dalam pendaran itu, Tuhan menaburkan rezeki," ujar Ki Dono Driyah.

Intertekstualitas pada cerpen Wajah Itu Membayang di Piring Bubur ini merujuk pada lakon monolog Genderuwo Pasar Anyar yang juga merupakan karya Indra Tranggono. Penggunaan simbol genderuwo dalam cerpen dan lakon monolog samasama merepresentasikan sistem kapitalis yang sudah merambah di Indonesia. Cerpen Wajah Itu Membayang di Piring Bubur di buat tahun 2011 sedangkan lakon monolog Genderuwo Pasar Anyar dibuat pada tahun 2014 dan dipentaskan oleh Khocil pada tahun 2016 di Taman Budaya Yogyakarta. Lakon monolog memiliki intertekstualitas 
LINGUA, Vol. 16, No. 1, Maret 2019

p ISSN: 1979 9411; e ISSN: 2442 238X

Http://lingua.pusatbahasa.or.id; Email:presslingua@gmail.com

Center of Language and Cultural Studies, Surakarta, Indonesia

Siregar, Sari Nelda \& Liliani, Else. 2019. Hegemoni pada Cerpen Wajah Itu Membayang

di Piring Bubur Karya Indra Tranggono: Analisis Wacana Kritis.

Lingua (2019), 16(1): 77 92. DOI: 10.30957/lingua.v16i1.576.

dengan cerpen yang terlebih dahulu dibuat. Tokoh yang dihadirkan pada cerpen dan lakon monolog memiliki kesamaan hanya saja pada monolog hanya menghadirkan tiga tokoh yang mendominasi yaitu: Murwad, Eyang Dano, dan Konglemerat Bragalba. Pada lakon monolog tersebut menggambarkan carut marut kondisi sosial masyarakat saat ini. Di mana orang lebih tergila-gila pada budaya kapitalisme dan globalisasi sehingga melupakan tradisi. Dalam naskah tersebut juga menggambarkan begitu derasnya gempuran toko-toko dan pasar modern, sehingga menggusur pasar tradisional yang mengakibatkan pengusaha-pengusaha kecil gulung tikar. Naskah tersebut sangat relevan dengan keadaan saat ini di mana hegemoni kapitalis merambah. Di mana tidak semua orang bisa melawan arus ini untuk masuk. Dalam monolog tersebut tergambarkan keangkuhan genderuwo, peran yang dimainkan oleh Khocil menyatakan bahwa seorang rakyat kecil hingga presiden tidak bisa melawan genderuwo tersebut.

\subsection{Dimensi Praktik Sosio-Budaya}

Analisis praktik sosio-budaya didasarkan pada asumsi bahwa konteks sosial yang ada di luar teks memengaruhi bagaimana wacana tersebut muncul. Praktik sosio-budaya dapat menentukan teks melalui mediasi dengan praktik wacana. Sebuah ideologi muncul dilihat dari hubungannya dengan teks dan dimediasi oleh bagaimana teks tersebut diproduksi dalam suatu proses praktik pembentukan wacana. Pemilihan kata, rujukan teks atau wacana yang digunakan oleh tokoh atau pengarang merupakan produk dari ideologi. Sosok Indra Tranggono adalah budayawan dan sastrawan ini telah menulis beberapa buku, di antaranya cerita pendek yang masuk dalam cerpen Kompas pilihan. Indra Tranggono yang lahir di Yogyakarta ini, aktif menjadi anggota pengurus Majelis Luhur Tamansiswa dan aktif menulis masalah sastra. Tulisa-tulisan Indra Tranggono selalu mengangkat fenomena dan kritik sosial yang terjadi di Indonesia tak jarang sering memasukkan unsur-unsur mitos Jawa ke dalam bagian cerita untuk mendukung maksud cerita tersebut. Berdasarkan pemilihan kata untuk mengkonstruksi bentuk hegemoni kapitalis dalam cerpen ini menggunakan simbol mitos hantu genderuwu yang dipercayai oleh masyarakat jawa. Pada praktik sosio-budaya saat ini sangat relevan karena sistem kapitalis sudah secara gamblang memasuki Indonesia.

Kapitalisme kini muncul dengan kemasan globalisasi yang semakin mengglobal pada masyarakat Indonesia. Reallitas yang terjadi pada bangsa Indonesia saat ini ternyata masih dibelenggu oleh kapitalisme. Berbagai institusi berhasil dikendalikan oleh pelaku kapitalis seperti: institusi ekonomi, agama, pendidikan, hukum, kesehatan, bahkan institusi keluarga sekalipun telah berhasil dikemudikan oleh kapitalisme tersebut. Hegemoni kapitalis membuat masyarakat menjadi masyarakat yang konsumtif. Dengan mudah kapitalisme mengarahkan logika berpikir bangsa Indonesia pada pola hidup konsumtif, yaitu sebuah pola hidup yang hanya bisa menggunakan dan masyarakat Indonesia seolah dibuat tidak untuk berpikir dengan adanya penyediaan segala sesuatu yang bersifat instant. Beberapa contoh di antaranya adalah dengan adanya yaitu: pertama, kartu kredit yang menyebabkan masyarakat membelanjakan uang mereka jauh lebih banyak dibandingkan dengan yang semestinya dan melebihi uang persediaan yang ada, membeli sesuatu yang tidak diperlukan dan bahkan 
LINGUA, Vol. 16, No. 1, Maret 2019

p ISSN: 1979 9411; e ISSN: 2442 238X

Http://lingua.pusatbahasa.or.id; Email:presslingua@gmail.com

Center of Language and Cultural Studies, Surakarta, Indonesia

Siregar, Sari Nelda \& Liliani, Else. 2019. Hegemoni pada Cerpen Wajah Itu Membayang

di Piring Bubur Karya Indra Tranggono: Analisis Wacana Kritis.

Lingua (2019), 16(1): 77 92. DOI: 10.30957/lingua.v16i1.576.

barangkali tidak mereka inginkan. Kedua, shopping atau jalan-jalan di mall membujuk masyarakat untuk membeli sesuatu yang tidak mereka butuhkan. Ketiga, jaringan TV Shopping dan cybermall membolehkan masyarakat berbelanja sampai 24 jam sehari, tujuh hari dalam seminggu, dengan cara demikian meningkatkan kemungkinan bahwa mereka akan membelanjakan uang mereka lebih daripada yang semestinya. Keempat, katalog-katalog memungkinkan masyarakat membeli produk yang diperlukan. Hal tersebutlah yang sedang menjerat masyarakat Indonesia menjadi masyarakat konsumtif.

Kaum kapitalis akan mengunakan berbagai cara untuk mencapai persaiangan pasar yang bebas mulai dari pasar modal sampai pada memakan perusahaan kecil. Contohnya, jika di suatu wilayah banyak terdapat toko kelontong yang kecil atau pasar tradisioal, maka cukup dibangun sebuah mal yang besar. Dengan itu toko-toko itu akan tutup dengan sendirinya dan mengalam kebangkrutan serta menghilangkan sosiobudaya masyarakat tersebut. Padahal secara hakikatnya proses belanja di pasar tradisional lebih luwes dan baik karena memakmurkan masyarakat Indonesia itu sendiri. Pada cerpen ini pengarang mengonstruksikan hegemoni kapitalis dengan simbol genderuwo yang mengubah pasar-pasar tradisional menjadi pasar modern. Saat ini, warga lebih memilih belanja di pasar modern karena pasar modern yang lebih bersih dan rapi serta dibangun berdekatan dengan pasar tradisional yang akhirnya akan menyebabkan matinya proses jual beli di pasar tradisinonal. Padahal secara esensinya, kegiatan jual beli di pasar tradisional yang menjadi tradisi masyarakat betapa tidak ketika pembeli dan penjual terlihat harmonis karena saling menyapa. Terdapat proses tawar menawar yang merupakan interaksi menyenangkan dan membangunkan keguyuban. Sebab, kadang orang pergi ke pasar tidak hanya sekadar untuk berbelanjan melainkan untuk mengobrol dengan pedagang, hingga terjadi interaksi yang menarik. Jadi, terdapat nilai-nilai menarik saat melakoni transaksi di pasar tradisional.

Hegemoni kapitalis yang dikontruksikan oleh pengarang merupakan bentuk praktik sosio-budaya saat ini. Secara realitanya sudah ada di mana-mana supermarkert yang menyedakan seluruh kebutuhan masyarakat dan tersedia dalam waktu 24 jam. Hegemoni kapitalis disimbolkan dengan genderuwo sebagai penguasa pasar yang kerap bersikap rakus dan hegemonik merupakan cerminan dari pelaku kapitalis. Semakin berkembangnya sistem kapitalis maka akan semakin membuat masyarakat terperdaya akan sistem tersebut yang secara pelan-pelan akan merugikan masyarakat itu sendiri. Kelakuan masyarakat yang sudah sangat mendewakan produk-produk kapitalisme membuat tantangan bangsa Indoensia itu sendiri untuk tidak terlalu jauh lagi masuk ke dalam sistem kapitalis yang sangat merugikan.

Pengarang di sini, memposisikan teks sebagai bentuk kritikan yang dihaluskan dengan mengangkat mitos hantu genderuwo. Dalam masyarakat jawa dipercayai bahwasanya genderuwo merupakan mahluk halus yang selalu menggangu kehidupan manusia dan memiliki sifat yang rakus dan hegemonik untuk memiliki sesuatu. Hal tersebut direpresentasikan dengan sistem kapitalis yang terjadi saat ini. Berdasarkan hal tersebut akan muncul beberapa ideologi yang terdapat dalam cerpen sehingga membentuk formasi ideologi. Ideologi dominan dalam cerpen karya Indra Tranggono ini adalah kapitalisme. Di mana terdapat hegemoni kapitalis yang muncul sebagai 
LINGUA, Vol. 16, No. 1, Maret 2019

p ISSN: 1979 9411; e ISSN: 2442 238X

Http://lingua.pusatbahasa.or.id; Email:presslingua@gmail.com

Center of Language and Cultural Studies, Surakarta, Indonesia

Siregar, Sari Nelda \& Liliani, Else. 2019. Hegemoni pada Cerpen Wajah Itu Membayang

di Piring Bubur Karya Indra Tranggono: Analisis Wacana Kritis.

Lingua (2019), 16(1): 77 92. DOI: 10.30957/lingua.v16i1.576.

bentuk kritik atas realita saat ini. Kelas dominan yang diduduki oleh tokoh wali kota Bragalba yang memiliki wewenang karena jabatannya bisa melakukan bentuk hegemoni kapitalis karena dengan sengaja membakar pasar tradisional dan membangun pasar modern/plaza. Sedangkan kaum subordinat di sini yang menjadi korban karena dituduh sebagai pelaku pembakar pasar adalah murwad. Murwad yang memiliki kelas sosial menengah ke bawah dengan mudah mendapat perilaku penindasan atas perilaku yang tidak dilakukannya terbukti dengan tokoh Murwad yang akhirnya masuk ke dalam sel tahanan. Relasi yang terbentuk dalam kedua kelas sosial ini tidak harmoni karena ideologi yang muncul dari pihak dominan adalah kapitalisme sehingga Murwad yang menjadi korban mencoba memberontak atas penindasan dan ketidakadilan yang terjadi pada dirinya dengan tidak menyerah.

Ideologi lain yang muncul dalam cerpen tersebut adalah militerisme. Tokoh yang berideologikan militerisme adalah Pemerika (Polisi) sebagai aparat negara yang dengan kekuasaan yang dimilikinya kerap berlaku hegemoni terhadap kelas subordinat. Sebagai aparat dominasi, tokoh-tokoh ini dengan jelas menunjukkan berbagai aksinya dalam menunjang tokoh-tokoh dominan atau penguasa. Polisi kerap menindas kelas subordinat seperti yang terjadi pada tokoh Murwad yang harus mengakui bahwa dirinyalah yang membakar pasar tersebut. Dalam cerpen tersebut bisa terjadi proses kerja sama antara pelaku kapitalis (wali kota Braglba) sebagai kelas yang lebih dominan dibanding polisi untuk melakukan diskriminasi tehadap tokoh Murwad. Sebab, melalui kewenangan polisi yang berideologi militerisme tersebut bisa dengan mudah menindas Murwad sebagai tokoh kelas subordinat.

Pada beberapa tokoh dalam cerpen ini juga memunculkan ideologi mistisme jawa yang masih sangat kental. Terbukti dengan kepercayaan masyarakat jawa akan mitos genderuwo yang berbadan besar kerap menganggu kehidupan manusia. Kehadiran Eyang Dono juga menguatkan ideologi mistisme jawa ada di dalam cerpen ini karena ketika merintis berdirinya Pasar Kliwon hingga berkembang pesat Eyang Dono bertapa selama 40 hari untuk mendapatkan wahyu pasar. Masyarakat jawa yang masih kental dengan tradisi kejawennya akan mempercayai ritual-ritual seperti bertapa dapat mengabulkan sebuah hajat yang diinginkan. Sebab ketika agama Islam disebarkan di daerah jawa melalui kebudayaan nilai-nilai mistis tersebut hingga saat ini masih dianut oleh sebagian masyarakat Jawa dan dengan masuknya agama Islam kerap kali juga dipadukan dengan ajaran-ajarn islam. Bentuk ideologi mistisme jawa juga ketika mempercayai bubur/ jenang gula jawa dapat menolak balak dan melalui jenang tersebut dapat menghaurkan doa-doa dan pengharapan kepada Tuhan.

Ideologi humanistik juga ditemukan pada cerpen ini. Humanistik secara umum yang memfokuskan dirinya ke jalan keluar umum dalam masalah-masalah atau isu-isu yang berhubungan dengan manusia. Humanisme telah menjadi sejenis doktrin beretika yang cakupannya diperluas hingga mencapai seluruh etnisitas manusia, berlawanan dengan sistem-sistem beretika. tradisonal yang hanya berlaku bagi kelompok etnis tertentu. Humanisme sebagai suatu aliran dalam filsafat, memandang manusia itu bermartabat luhur, mampu menentukan nasib sendiri, dan dengan kekuatan sendiri mampu mengembangkan diri. Pada cerpen tersebut ideologi ini muncul ketika Eyang 
LINGUA, Vol. 16, No. 1, Maret 2019

p ISSN: 1979 9411; e ISSN: 2442 238X

Http://lingua.pusatbahasa.or.id; Email:presslingua@gmail.com

Center of Language and Cultural Studies, Surakarta, Indonesia

Siregar, Sari Nelda \& Liliani, Else. 2019. Hegemoni pada Cerpen Wajah Itu Membayang

di Piring Bubur Karya Indra Tranggono: Analisis Wacana Kritis.

Lingua (2019), 16(1): 77 92. DOI: 10.30957/lingua.v16i1.576.

Dono hadir sebagai penolong Murwad ketika menjadi korban kebakaran yang terjadi di Pasar Kliwon. Eyang Dono mencoba menceritakan sosok genderuwo pengusa pasar. Melalui simbol genderuwo Eyang Dono ingin menyampaikan kepada Murwad akan fenomena sistem kapitalis yang merusak tradisi masyarakat.

Berdasarkan uraian ini terdapat formasi ideologi yang membentuk terjadinya sebuah tatanan masyarakat yang hegemonik dalam cerpen yaitu: ideologi kapitalisme, otoriterisme, mistisme, dan humanisme. Ideologi yang paling dominan adalah bentuk hegemoni dari idiologi kapitalisme. Ideologi-ideologi itu direpresentaikan oleh pengarang melalui tokoh-tokoh. Formasi ideologi dapat dilihat pada tabel berikut.

Tabel 1. Formasi Ideologi

\begin{tabular}{|c|c|c|c|c|}
\hline Tokoh & Kelompok & Kategori & Formasi Ideologi & $\begin{array}{l}\text { Ideologi } \\
\text { dominan }\end{array}$ \\
\hline Bragalba & Hegemoni & Pemimpin & Kapitalisme & Kapitalisme \\
\hline Polisi & Pro-hegemoni & Aparat negara & $\begin{array}{l}\text { Otoriterisme } \\
\text { Kapitalisme }\end{array}$ & Otoriterisme \\
\hline Genderuwo & Hegemoni & Simbol kapitalis & Kapitalisme & Kapitalisme \\
\hline Eyang Dono & $\begin{array}{l}\text { Kontra- } \\
\text { hegemoni }\end{array}$ & $\begin{array}{c}\text { Perintis Pasar } \\
\text { Kliwon }\end{array}$ & $\begin{array}{l}\text { Mistisme } \\
\text { Humanisme }\end{array}$ & Mistisme \\
\hline Murwad & $\begin{array}{l}\text { Kontra- } \\
\text { hegemoni }\end{array}$ & Rakyat & $\begin{array}{l}\text { Mistisme } \\
\text { humanisme }\end{array}$ & Humanisme \\
\hline Sumbi & $\begin{array}{c}\text { Kontra- } \\
\text { hegemoni }\end{array}$ & Rakyat & $\begin{array}{l}\text { Mistisme } \\
\text { Humanisme }\end{array}$ & Humanisme \\
\hline
\end{tabular}

Tabel 1 menunjukkan kelompok hegemoni, pro-hegemoni, dan kelompok kontrahegemoni. Kelompok hegemoni adalah aktor utama terjadinya hegemoni (kelompok dominan), sedangkan kelompok pro-hegemoni adalah tokoh yang mendukung terjadinya hegemoni, kelompok kontra-hegemoni terdiri dari orang yang menentang terjadinya hegemoni (kebudayaan bangkit).

\section{SIMPULAN}

Cerpen Wujud Itu Membayang di Piring Bubur mengangkat persoalan ekonomi politik. Dalam cerpen ini terdapat formasi ideologi yang membentuk sebuah hegemoni yang di antaranya adalah kapitalisme. Hegemoni kapitalis terjadi karena pelaku dominan yang ingin menguasai perekonomian dengan sistem kapitalis. Sistem kapitalis yang terjadi saat ini dengan cara memakan usaha-usaha kecil dengan membangun mall yang menyebabkan pengusaha kecil menjadi gulung tikar. Dengan melakukan pembacaan analisis wacana kritis terhadap cerpen ini, ada tiga hal yang ingin disampaikan oleh pengarang melalui mitos genderuwo yang dipercayai masyarakat jawa. Pertama, menyadarkan masyarakat Indonesia bahwasanya bangsa Indonesia sudah terbelenggu dengan sistem kapitalis. Kedua, sebagai bentuk kritik terhadap fenomena yang terjadi saat ini bahwasanya pelaku kapitalis akan melakukan berbagai cara untuk mencapai tujuan termasuk memakan atau menghilangkan pasar-pasar tradisonal menjadi pasar modern. Ketiga, mengkritik masyrakat Indonesia yang sudah 
LINGUA, Vol. 16, No. 1, Maret 2019

p ISSN: 1979 9411; e ISSN: 2442 238X

Http://lingua.pusatbahasa.or.id; Email:presslingua@gmail.com

Center of Language and Cultural Studies, Surakarta, Indonesia

Siregar, Sari Nelda \& Liliani, Else. 2019. Hegemoni pada Cerpen Wajah Itu Membayang

di Piring Bubur Karya Indra Tranggono: Analisis Wacana Kritis.

Lingua (2019), 16(1): 77 92. DOI: 10.30957/lingua.v16i1.576.

mulai menjadi masyarakat yang konsumtif dengan berbagai hal yang instan. Keempat, memasukan ideologi kapitalis yang menjadi dominan dalam cerpen sebagai bentuk relevansi nyata yang terjadi saat ini.

\section{DAFTAR PUSTAKA}

Damono, Sapardi Djoko. (1979). Sosiologi Sastra: Sebuah Pengantar Singkat. Jakarta: Pusat Pembinaan dan Pengembangan Bahasa.

Eriyanto. (2015). Analisis Wacana Pengantar Analisis Teks Media. Yogyakarta: LkiS.

Fairclough, Norman. (1995). Critical Discourse Analysis: papers in the critical study of language. London: Longman.

Faruk. (1994). Pengantar Sosiologi Sastra: dari Strukturalisme Genetik sampai Postmodernisme Yogyakarta: Pustaka Pelajar.

Nurhadi. (2004). Analisis Hegemoni Pada Iblis Tidak Pernah Mati Karya Seno Gumira $\begin{array}{lllll}\text { Ajidarma. } & \text { LITERA. } & \text { Vol. } & 1 & \text { (25), }\end{array}$

https://journal.uny.ac.id/index.php/litera/article/view/6768

Wahyuni, Tri. (2013). Sosiologi Sastra Alan Swingewood Sebuah Teori. Jurnal $\begin{array}{llll}\text { Poetika. } & \text { Vol. } & 1 & \text { (1), }\end{array}$

https://jurnal.ugm.ac.id/poetika/article/view/10384/7839

Wellek, Rene dan Austin Warren. (2014). Teori Kesusastraan. Jakarta: PT Gramedia.

http://kotajogja.com/6162/pentas-monolog-khocil-birawa-genderuwo-pasar-anyar/ akses 20 Januari 2019

https://id.wikipedia.org/wiki/Pasar Kliwon, Surakarta akses 20 Januari 2019

https://www.merdeka.com/peristiwa/berburu-praktik-prostitusi-terselubung-di-solo.html akses 21 Januari 2019

https://travel.kompas.com/read/2017/08/14/165200027/kayanya-tradisi-jawa-padasemangkuk-bubur akses 21 Januari 2019

http://misteriihantu.blogspot.com/2015/05/mitos-hantu-genderuwo-di-masyarakat.html akses 21 Januari 2019 